\title{
Sztankó Éva
}

\section{Az Európai Unió liberalizált energiapiaca}

\author{
Dilemmák és kérdések
}

Az egységes európai energiapiac - az elmúlt években tapasztalható elörelépések ellenére - még nem valósult meg. Az energiahálózatok teljes körü integrációja és a nemzeti piacok teljes megnyitása érdekében további alapvető változtatásokra van szükség, hogy az energiaellátás biztonságos, alacsony költségü és fenntartható lehessen. Ehhez a meglévő hálózatok korszerüsítése mellett ki kell építeni a keresleti és a kínálat oldal rugalmasságát is biztositó integrált infrastruktúrát; ez alapvető feltétele annak, hogy új technológiák, új szereplök és komplementer szolgáltatók jelenjenek meg a piacon. A következő elemzés áttekinti a piaci integráció eredményeit, a liberalizációt még hátráltató korlátokat és a lehetséges kezelési módokat. A változásokat kiváltó okok ismertetése mellett kísérletet tesz az európai energiaszektorban végbemenő jelentős átalakulások és a legfontosabb feladatok bemutatására is.

Journal of Economic Literature (JEL) kódok: Q40, Q41, Q49

Kulcsszavak: Energiapiac, liberalizáció, intelligens hálózatok

Az Európai Unió fokozatosan növekvő energiaimport-függőssége ${ }^{1}$ ráirányítja a figyelmet arra, hogy a harmadik (potenciális exportőr) országokkal jó külügyi kapcsolatokat kell kiépíteni, valamint sikeres belső piaci integrációra van szükség (mivel a liberalizáció belső és külső piaci oldala szorosan összefügg, a belső piaci liberalizáció alapfeltétele az eredményes külsőnek). Ehhez kapcsolódott az Európa Tanács - 2011-es nyilatkozata, amely szerint - 2014-ig meg kell valósítani az EU belső energiapiacát ${ }^{2}$. Ez az integráció alkotja az egységes belső piac kialakításának egyik legfontosabb elemét. Az ambiciózus célkitüzés megvalósítása azonban még várat magára. A diverzifikációt, illetve az egységes európai gázpiac létrejöttét elősegítő infrastrukturális fejlesztések (például Észak-Déli csatorna LNG terminálokkal, Nabucco3) késedelmet szenvednek, illetve leálltak, ugyanakkor az egységes uniós árampiac 2014-re tervezett létrehozása - az árampiacok fokozatos összekapcsolásával - már karnyújtásnyira került.

Sztankó Éva (PhD) a Pannon Egyetem Pénzügytan Tanszékének docense. E-mail: esztanko@mvm.hu.

1 A 2013-as közel 53 százalékos szintröl 2030-ra 70 százalék fölé emelkedhet a függöség. Az energiaimport viszonylag szüken behatárolható régiókból érkezik. A földgázimport közel 40 százaléka például az egykori Szovjetunó tagállamaiból származik. Oroszország pedig hagyományosan nemcsak bevételi forrásként, hanem a nemzetközi politikai érdekérvényesités kiemelt eszközeként is tekint a földgázra.

2 Az Európa Tanács 2011. február 4-i energiaügyi zárónyilatkozata.

${ }^{3}$ A nem megfelelő finanszírozási háttér és a könnyen termelésbe állitható lelóhely hiánya miatt a Nabucco gázvezeték sorsa kétséges, de más európai projektek (vezetékek, LNG terminálok) épitése is lassan halad. 
A belső áram- és földgázpiac létrehozása 1996-tól kezdve azon a kettős elven alapult, hogy egyrészt minden fogyasztó a saját maga által választott szolgáltatótól szerezheti be az energiát (nemzeti hovatartozástól függetlenül), másrésztaz egységes piac kedvező hatású lesz az energiaárakra és ösztönözni fogja a beruházásokat. Ennek érdekében azóta három egymást követő jogalkotási csomagot fogadtak el. Az 1990-es évek második felében hatályba léptetett közös szabályokról szóló irányelveket 2003-ban egy második jogalkotási csomag követte, amely lehetővé tette új villamosenergia- és földgázszolgáltatók belépését a tagállamok piacaira, valamint a szabad szolgáltatóváltást az ipari és háztartási fogyasztók számára ${ }^{4}$.

A következö, 2009-ben elfogadott úgynevezett 3. energiacsomag célja a belső energiapiac további liberalizálása és a strukturális hiányosságok felszámolása volt. A 2011-ben hatályba léptetett jogszabályokat azonban sok tagállam még mindig nem ültette át a gyakorlatba, illetve nem történt meg teljes körủ végrehajtásuk, ami viszont veszélyezteti az eddig elért jelentős eredményeket is. Az Európai Bizottság ezért kiemelten ellenőrzi a jogszabályok tagállami adaptációját, a versenyelöírások - és különösen a trösztellenes regulák betartását. A jogszabályokban foglaltak végrehajtásának elmulasztása miatt 2011 óta több kötelezettségszegési eljárás indult a villamosenergia- és a földgázellátás területén, amelyeknek közel a fele még nem zárult le (European Comission 2012:155)

$\mathrm{Az}$ egységes belső energiapiac előnyei lassan láthatóvá válnak, bővült a szolgáltatások választéka, emelkedett a színvonal, s a szolgáltatók egymással versenyezve igyekeznek kielégíteni a fogyasztók legkülönbözőbb igényeit. Az európai energiahálózatok és -rendszerek teljes körű integrációjára és a nemzeti piacok teljes megnyitására azonban még várni kell. Abban az esetben viszont, ha nem sikerül felgyorsítani a változásokat, akkor a részleges liberalizáció egy kevésbé megbízható, relatíve drága európai energiarendszert hozhat, ami ronthatja az európai ipar versenyképességét. A gazdasági és pénzügyi válság miatt pedig újabb strukturális reformok válhatnak szükségessé.

A következőkben áttekintjük a belső energiapiac müködőképessé tételéhez szükséges bizottsági intézkedéscsomagok kulcsterületeit, az állandóan változó környezet kihívásaihoz igazodó energiapiac folyamatos fejlesztésének legfontosabb feladatait és a végrehajtási lehetőségeket. Olyan piac létrehozása a cél, ahol a fogyasztóknak valóban van választási lehetőségük, az érintett cégek pedig szabadon, korlátozásmentesen nyújthatják szolgáltatásaikat.

\section{Az integrált energiapiac előnyei}

Egy integrált, rugalmas és felhasználóbarát belső energiapiac középpontjában az energia végfogyasztói állnak. Olyan feltételeket kell biztosítani számukra, hogy magas színvonalú szolgáltatásokat vehessenek igénybe, számukra vonzó feltételek mellett. Ez jelenleg nem így van. A villamosenergia-termelés például továbbra is erösen koncentrált, nyolc tagállamban a termelés közel 80 százaléka még mindig a hagyományosan jelen lévő szereplők (inkumbens

\footnotetext{
${ }^{4}$ A szabad szolgáltatóváltás az ipari fogyasztóknál 2004 júliusától, a háztartásiaknál 2007 júliusától lehetséges.

5 2011-ben a villamos energia területen 17, gázügyben pedig 13 eljárás indult; 2013. második negyedévében még öszszesen 11 eljárás volt folyamatban.
} 
vállalkozások) ellenőrzése alatt áll. A problémát tovább fokozza, hogy a tagállamok között kevés a rendszerösszekötő kapacitás, ami eltérő árakhoz és ellátási feltételekhez vezetett ${ }^{6}$.

A tagállami energiapiacok összességükben annak ellenére nem kellőképpen átláthatóak és nyitottak az új szereplők számára, hogy a 90-es évek vége óta uniós ágazati szabályozással próbálják az integrációt megvalósítani. Az energiahatékonyságot növelö, gazdaságilag rentábilis beruházások nem elegendőek, és a piac által vezérelt beruházási döntések mellett ma még meghatározó szerepük van a különböző állami támogatási formáknak. A fogyasztói elégedettség pedig a viszonylag versenyképes piacú tagállamokban is alacsony szintet mutat.

Mindezek ellenére, a belső energiapiacnak immár vitathatatlan előnyei is megmutatkoznak. A villamosenergia-szektor szereplöi közül számos társaság egyszerre több országban is jelen van, s a tagállamok közel 60 százalékában a háztartások és a kisebb vállalkozások a gyakorlatban is élnek a szabad szolgáltatóváltás lehetőségével. Az ezzel járó potenciális előnyök megismertetése nagyarányú átrendeződéshez vezetett a tájékozott és aktív fogyasztók körében (ECME Consortium (2010) . A piacnyitás, a határokon átnyúló kereskedelem növekedése, valamint az uniós jogszabályok hatékony érvényesítése révén pedig ellenőrzést lehet gyakorolni az árak alakulása felett is, ezáltal lehetővé téve a versenyképesebb árképzést (European Comission 2012:39) ${ }^{8}$.

A fogyasztók számláiban az energiaár mellett az átviteli és elosztóhálózatok után fizetendő rendszerhasználati díjak, valamint az adók és az illetékek is jelentős hányadot képviselnek. Az adókat és az illetékeket az egyes tagállamok saját nemzeti érdekeiket szem elött tartó politikájuknak megfelelően határozzák meg, mértékük eltérő a fogyasztók különböző csoportjai számára. Néhány tagállamban az adók és illetékek együttesen a végső számlának akár az 50 százalékát is elérhetik. Az EU-15-ök területén a fogyasztókkal megfizettetett, az energiaszámlákba beépülö adók aránya átlagosan (villamos energia, földgáz) az 1998-as 22 százalékról 2010-ben 28 százalékra emelkedett (COM 2011c). Ez a növekedés a fogyasztás és a környezetszennyezés nagyobb arányú megadóztatásának érdekében történik.

Az energiaárak érdemi csökkentésével várhatóan a jövőben sem lehet számolni, többek között az EU elöregedő energiarendszereinek karbantartásához és korszerüsítéséhez szükséges beruházások miatt, ami növeli a fajlagos előállítási költségeket. A belső energiapiac ugyanakkor lehetőséget teremtene a beruházások költséghatékonyabb megvalósítására és a szolgáltatók közötti verseny erősítésére, aminek a legnagyobb haszonélvezői a fogyasztók lennének.

Az Európai Bizottság felmérése szerint, a fogyasztók jelentős (mintegy 13 milliárd eurós) megtakarítást tudnának elérni, ha olcsóbb energiaszolgáltatási tarifákat választanának (Energy Market Observatory 2012). A tanulmányból kiderül, hogy csupán minden harmadik fogyasztó hasonlítja össze a cégek ajánlatait, pedig a szolgáltatóváltást pénzügyi költségek nélkül megtehetnék. A lakosság nagy része azonban továbbra sincs tisztában a piac nyújtotta lehetőségekkel, vagy nem képes élni azokkal. Ezért intézkedési tervet

\footnotetext{
6 A Bizottság trösztellenes vizsgálatai számos elörelépést eredményeztek már ezen a téren. Például a német piac megnyitása szempontjából mérföldkőnek tekinthetö, hogy 2008-ban az E.ON vállalta átviteli hálózatainak eladását. Svédországban a szomszédos országokkal folytatott exportot akadályozó átviteli rendszert (rendszerösszekötő kapacitást) bövítették.

7 Például Svédország, Egyesült Királyság, Írország, Belgium, Csehország.

8 Az elmúlt években a primer energiahordozó árak éves szinten 14 százalékkal nőttek a nyersolaj, közel 10 százalékkal a gáz és 8 százalékkal a szén esetében. A villamos energia nagykereskedelmi ára viszont az EU-n belül ennél jóval kisebb ütemü, 3,4 százalékos növekedést mutatott.
} 
dolgoztak ki a fogyasztói információk minőségének és elérhetőségének javítására, valamint a megalapozott döntések meghozatalát elösegítő, könnyen kezelhető ár-összehasonlító eszközök kialakítására.

Az integráció eredményeképpen nagyobb likviditású és átláthatóbb nagykereskedelmi piacok jöttek létre, s likviditásuk fokozatosan javul. A tagállamok villamosenergiapiacainak fokozatos összekapcsolása (market coupling) a határokon átnyúló kereskedelem növekedését eredményezi. Ennek következtében a villamosenergia-tőzsdék likviditása javul, az árjelzések az eltérő régiós árszintek közötti kiegyenlítődés irányzatát erősítik9

A gáztársaságok közötti, soha nem látott mértékü kereskedelem hatására a gázkereskedelmi platformok (földgázelosztó központok) 2003 és 2011 között látványos, tízszeres növekedést mutattak, kedvező hatást gyakorolva ezzel az uniós piacok nagykereskedelmi gázáraira ${ }^{10}$. A kereskedési csomópontokban az árkülönbségek nem jelentösek, köszönhetően a sürűn kiépített földgázelosztó és szállító vezeték hálózatnak (European Comission 2012:Map 1).

Az EU gázpiaca jelenleg három-négy nagyobb beszállítóra támaszkodhat az egyre növekvő importigény kielégítésében, amíg azonban a nyugati részen több exportör is versenyhelyzetben van egymással, keleten az orosz földgáz domináns a piacon, ami komoly biztonsági kockázatot jelent ${ }^{11}$. Ezért uniós szinten kiemelt feladatként kezelik a nemzeti rendszerek összekapcsolását és az összekötő vezetékek „kétirányúsítását”. A szállítókapacitások növelésére pedig újabb fejlesztési elképzelések születtek (például Déli Áramlat, Jamal 2) ${ }^{12}$.

A nagykereskedelmi energiapiacok integritásáról és átláthatóságáról szóló, 2011-ben elfogadott REMIT rendeletnek (REMIT 2011) köszönhetően a hatékony piacellenőrzés is megindult ${ }^{13}$. A rendelet célja a kereskedelmi gyakorlatok tisztességes voltának szavatolása az európai energiapiacokon. Tiltja a bennfentes információk használatát, a manipulatív tranzakciókat, a félrevezető információk terjesztését, és felhatalmazza az ACER-t (Agency for the Cooperation of Energy Regulators - Energiaszabályozók Együttmüködési Ügynöksége), hogy figyelje a kereskedelmet, vizsgálja ki a piaci visszaéléseket, illetve koordinálja a tagállamokkal a megfelelő szankciók alkalmazását. Az alkalmazandó szankciókért és végrehajtásukért ugyanakkor a tagállamok a felelösek.

Az elmúlt években jelentős fogyasztáscsökkenés volt tapasztalható az európai áram- és földgázpiacokon, elsősorban a gazdasági válság, majd az abból kifejlődő adósságválság miatt. A gazdasági aktivitás mérséklődése az energia iránti igény csökkenésén keresztül egyértelmüen nyomon követhetö. Miközben a kereslet visszaesett, az energiaellátásban

\footnotetext{
9 Erre irányuló kezdeményezés volt a cseh-szlovák-magyar másnapi villamosenergia-piacok 2012. szeptemberi összekapcsolása, ami alapvető változásokat hozott az árakban. A régiós másnapi árak már közelítően megegyeznek. A piac összekapcsolás a román és a lengyel piacok bevonásával folytatódik (a Magyar Energetikai és Közmű-szabályozási Hivatal közleménye, 2013. július).

10 Az EU nagykereskedelmi energiaárait nagyrészt továbbra is a fosszilis tüzelőanyagok ára határozza meg. Az Egyesült Államokban viszont az olyan nem hagyományos szénhidrogének, mint a palagáz kitermelése egyre fokozódik, aminek ármérséklö hatása van. A palagáz térnyerése Európában még bizonytalan, számos tényező hátráltatja-például a technológia hiánya és a jogszabályi környezet.

11 Az orosz földgáznak való kitettség régiós szinten meghaladja a 65 százalékot. A tényleges orosz irányú kitettség vélhetően ennél is magasabb, mivel számos esetben a nyugati betáplálási pontokon is eredetileg Oroszországból származó földgáz "re-exportja" valósul meg.

12 A Déli Áramlaton orosz gáz érkezhet Dél- és Közép-Európába Ukrajna elkerülésével, a Jamal-Európa gázvezeték második szakaszának tovább építése pedig Lengyelország, Szlovákia és Magyarország gázellátását javítaná.

13 REMIT: Regulation on Wholesale Energy Market Integrity and Transparency.
} 
olyan új technológiák (például microgeneration technologies ${ }^{14}$ ) jelentek/jelennek meg, amelyek részben vagy akár teljes egészében is függetleníthetik a fogyasztókat a hálózati ellátástól, hozzájárulva ezzel a háztartások energiafogyasztásának optimalizálásához. Szintén a fogyasztás költséghatékonyságát növeli az intelligens technológiák és hálózatok elterjedése. Az intelligens mérörendszerek alkalmazásával az aktuális energiafogyasztást a piaci ár változásaihoz lehet igazítani.

A felmérések szerint, a háztartások villamosenergia-költsége több mint 10 százalékkal mérsékelhető az úgynevezett smart metering (okos mérő) rendszerekkel, de automatizált háztartási készülékek használatával még ennél nagyobb megtakarítás is elérhető (Stromback és szerzötársai 2011). A szolgáltatók (például energiaszolgáltatás, telekommunikáció) közötti együttműködéssel pedig tovább javítható a kapcsolódó beruházások költséghatékonysága.

$\mathrm{Az}$ átviteli hálózatokhoz való nyílt és diszkriminációmentes hozzáférés (Third Party Access - TPA) hiánya meggátolhatja, hogy az új piaci belépők tisztességes feltételek mellett versenyezhessenek. A meglévő uniós jogszabályok alapján a tagállamok kötelesek szétválasztani (unbundling) az átviteli és az elosztó hálózati üzletágaikat ${ }^{15}$. Ennek nyomán egy új, kizárólag az átvitelre koncentráló iparág jött létre, ahol egyre hangsúlyosabbá válik a határokon átnyúló rendszerösszekötő kapacitások kiépítése és bővítése. Az átviteli rendszerirányítók európai hálózatai (ENTSO-E és ENTSO-G) ${ }^{16}$, valamint az ACER fontos szerepet játszanak abban, hogy a meglévő átviteli hálózati infrastruktúra használata minél hatékonyabb legyen, és az új infrastruktúrák tervezése, fejlesztése, megépítése kizárólag az európai érdekekkel összhangban történhessen.

Az Európai Unión belüli hatékony TPA garantálása érdekében szükséges az átviteli rendszerüzemeltetők közötti regionális együttmüködések folyamatos fejlesztése és a szabályozói keretek összehangolása. Az egységes müszaki elöŕások bevezetésével tovább növelhető az energiahálózatok hatékonysága, a szolgáltatók és a felhasználók számára könnyebbé válhat az infrastruktúrához való hozzáférés, a határokon átnyúló kereskedelem tranzakciós költségei pedig csökkenthetők.

A földgáz esetében a szük keresztmetszetek kezelésére és a csővezetékek kapacitására vonatkozó új szabályok segítségével számolhatók fel a hálózati hozzáférést gátló akadályok. A villamos energiánál pedig a határokon átnyúló kiegyenlítő piacok és a likvid, napon belüli ügyletek piacának ${ }^{17}$ új müszaki elöírásai/szabályai (az intelligens hálózatokkal közösen) hivatottak növelni a rendszer rugalmasságát és elösegíteni a megújuló energiaforrásokból

\footnotetext{
14 Közvetlenül a fogyasztás helyére telepített háztartási méretű kiserőművek (például gáz-, nap- és szélerőmű). Megjegyzés: a Magyar Energetikai és Közmü-szabályozási Hivatal (MEKH) 2008 és 2012 közötti időszakra vonatkozó adatai szerint számuk több mint tízszeresére, beépített kapacitásuk pedig közel húszszorosára nőtt 2008-hoz képest.

${ }^{15}$ A 3. energetikai szabályozási csomag keretében elfogadott villamos energia és földgáz irányelvek új szabályokat rögzítenek az energiapiaci átviteli hálózat üzemeltetőjének és üzemeltetésének szétválasztására. Az irányelv három lehetséges szétválasztási modellt tartalmaz, amelyek alkalmazásáról a tagállam dönthet: teljes tulajdonosi szétválasztás; független rendszerüzemeltető (Independent System Operator - ISO); független átviteli/szállítási rendszerüzemeltető (Independent Transmission Operator - ITO; Distribution System Operator - DSO).

16 ENTSO-E/G: European Network of Transmission System Operators for Electricity/Gas.

17 A napon belüli ügyletek piacai és a kiegyenlítő piacok segítségével az egyes szereplök (beleértve a fogyasztókat is) termelésüket és fogyasztásukat a változó körülményekhez, legföképpen az árak alakulásához tudják igazítani. A likvid, napon belüli ügyletek piacára a kínálati és a keresleti ütemezések óránkénti rendszerességgel történő kiigazítása érdekében van szükség, ami Európában még nem elterjedt gyakorlat. A határokon átnyúló kiegyenlítő piacoknak köszönhetően el lehet majd kerülni a kiegyenlítő szolgáltatások kizárólag nemzeti közbeszerzéséhez kapcsolódó felesleges költségeket. Ezekkel a rendelkezésekkel, a határokon átnyúló viszonylatban, a kereslet és a kínálat mindenkor egyensúlyban lehet.
} 
származó villamos energia piaci integrációját. Ennek köszönhetően a megújuló forrásokból energiát termelők számára is lehetővé válhat, hogy egy olyan versenypiac teljes jogú résztvevői legyenek, ahol a megújuló energia változékony kínálata mindig megtalálja a megfelelö keresletet. A termelők fokozatosan olyan feladatokat is vállalhatnak, amelyek a hagyományos villamos energia termelökhözköthetők, például a kiegyenlítő energiapiacokon való részvételt.

\section{Hogyan javítható tovább az energiapiaci integráció?}

\section{A 3. energiacsomag maradéktalan végrehajtása}

A 3. energiacsomag végrehajtásához kapcsolódó késedelmes tagállami implementációk (például a piac megnyitása, a fogyasztók védelme) kedvezőtlen hatást gyakorolnak minden szereplőre. Ennek következtében az alapvetően fontos beruházások vagy nem a legalacsonyabb költségek mellett valósulnak meg, vagy teljes egészében elmaradnak. A versenypiac megvalósítása előtt álló egyik fő akadály tehát továbbra is a belső energiapiaci jog tagállami adaptációjának elmaradása. Úgy tűnik, nem minden EU-ország elkötelezett az egységes energiapiac kialakítása mellett, a legnagyobb tagok ma teljesen eltérő energiastratégiát követnek.

\section{Egyenlö versenyfeltételek megteremtése}

$\mathrm{Az}$ egyenlő versenyfeltételek megteremtése és fenntartása különösen olyan piacokon nagyjelentőségü, ahol a régi szereplöknek hagyományosan biztosított előnyök hátráltatják az újak piacra lépését. Ezért, a piaci torzulások megakadályozása érdekében, a Bizottság továbbra is szigorúan ellenőrizni kívánja a versenykorlátozó megállapodásokra és az állami támogatásokra vonatkozó szabályok betartását.

A belső piaci szabályok és a likvid regionális energiatőzsdék megnyitják az uniós energiapiacot a harmadik országok társaságai előtt is. A villamosenergia- és földgázimportra vonatkozó korlátozások és vámok felszámolásával pedig uniós szintủ energiakereskedelem kialakítása a cél. A közel 500 millió fogyasztót ellátó belső energiapiac így hozzájárulhat az uniós társaságok versenypozíciójának megerősítéséhez a nemzetközi kereskedelemben - amellett, hogy az EU határain belül a harmadik országok társaságait az európaiakkal megegyező jogok és kötelezettségek illetik meg.

\section{A regionális különbségek mérséklése}

$\mathrm{Az}$ energiapiac fejlődése gazdasági értelemben véve igen eltérő képet mutat az egyes tagországokban ${ }^{18}$. A szakadék áthidalásában fontos szerepet játszanak a regionális kezdeményezések, amelyek feladata többek között a regionális földgázelosztó központok és a villamosenergia-tőzsdék létrehozása, valamint az EU minden tagországára kiterjedő teljes villamosenergia-piaci összekapcsolás megvalósítása (COM 2010). Azokban a tagállamokban azonban, ahol csak egyetlen szolgáltató van jelen, és nincsenek meg az

${ }^{18}$ A földgázpiacon például jelentős különbség tapasztalható az Európai Unió északnyugati és keleti területei között. 
összekapcsolást biztosító hálózatok, a regionális piaci intézkedések eddig nem vezettek eredményre. A továbblépéshez alapvető reformokra van szükség. A tagországok elsősorban a határokon átnyúló szolgáltatások infrastrukturális fejlesztéseinek támogatásával és a piacra lépést hátráltató akadályok felszámolásával segíthetik a versenypiac kiépítését.

\section{Fogyasztóközpontú piac kialakítása}

A belső piac adta fogyasztói lehetőségek minél hatékonyabb kihasználáshoz a fogyasztóvédelmi szabályok érvényesítése kétségkívül fontos, de nem elegendő. Ösztönözni is szükséges a fogyasztókat arra, hogy a szolgáltatások passzív igénybe vevőiből tájékozott és aktív fogyasztókká váljanak, képesek legyenek jogaik csorbítatlan érvényesítésére.

A kis- és középvállalkozások, valamint a háztartások az ipari nagyfogyasztókkal összehasonlítva sokkal passzívabbak, nem használják ki a szolgáltatások árkülönbségeiben rejlö lehetőségeket, ami részben a nem kellően hatékony fogyasztóvédelemmel, az átláthatóság és a fogyasztóbarát információk hiányával magyarázható. Ezt támasztja alá a Bizottság 2011-ben végzett felmérésének eredménye is, ahol az energiapiacok fogyasztói elégedettsége a vizsgált 30 szolgáltatói piac rangsorában a 26. helyen (villamos energia), illetve a 21. helyen (földgáz) végzett (European Comission 2012: part III.) ${ }^{19}$.

A 2013-ig kiépült belső energiapiac még nem elégíti ki maradéktalanul a fogyasztók szükségleteit és elvárásait, mivel azok magas árakkal, korlátozott választékkal, és általában a szolgáltatások alacsony színvonalával, illetve a szolgáltatóváltás nehézségeivel szembesülnek.

\section{A szabályozott árak fokozatos megszüntetése}

Egy jól müködő liberalizált energiapiacon a fogyasztók a szolgáltatások és a kapcsolódó díjszabások széles köréből választhatnak, ami egyúttal ösztönzőleg hat a hatékonyabb energiafelhasználásra is. A szolgáltatók egy része az ártudatos fogyasztókat célozza meg, míg mások a szolgáltatás minőségére helyezik a hangsúlyt, vagy az energiaellátást hozzáadott értéket képviselő kiegészítő szolgáltatásokkal kombinálják (például informatika, távközlés). Noha a villamosenergia- és földgázpiacon megindult a nyitás, még korlátozott a beszállítók választéka és gyakori a szabályozott árképzés. Mindez akadályozza a társaságokat az igényekhez rugalmasan igazodó, vonzó díjszabások alkalmazásában.

Néhány országban az állam az árakat bizonyos fogyasztói csoportok - vagy valamennyi csoport-számára a piaci költségek alattállapítja meg. Az energiaipari társaságok számára ez (az adott szegmensben) veszteséget jelent, s nem ösztönöz hatékony energiafelhasználásra. A szabályozott árak egyes esetekben az államháztartás hiányához is vezethetnek, amely további, komoly összegű terhet rakhat a fogyasztók/adófizetők vállára. Egyértelmű tehát, hogy az ilyen intézkedések hosszú távon gazdaságilag nem tarthatók fenn és gátolják a versenyképes piac kialakulását/fejlődését.

\footnotetext{
19 Az uniós energiapiacok fogyasztói megítélése összességében lesújtó képet mutatott. Mindkét piacon (villamos energia, földgáz) igen alacsonyak voltak a pontszámok a választási lehetőségek, az összehasonlíthatóság, a szolgáltatók és a díjrendszerek közötti átjárhatóság tekintetében. Mindez arra enged következtetni, hogy a fogyasztók egyelöre nem tudják teljes mértékben kihasználni a piaci liberalizáció nyújtotta megtakarítási lehetőségeket.
} 
A szabályozott árak akkor sem nyújtanak valós árjelzést a beruházások megvalósításához, ha fedezik a megvalósítás és üzemeltetés költségeit. A befektetők szemében ez politikai befolyásra utal, ami csökkentheti a beruházási aktivitásukat.

Annak ellenére, hogy néhány tagállamban az energiaárak már a kiskereskedelmi fogyasztók számára is mentesek az állami beavatkozástól ${ }^{20}$, az Európai Unión belül még nagyon változatos a kép. A Bizottság ragaszkodik a szabályozott árak fokozatos leépítéséhez (a kiskereskedelmi területeken is), és kilátásba helyezte, hogy a piaci alapú árképzést nem teljesítőkkel szemben kötelezettségszegési eljárást indít (Bírósági ítélet 2010)21.

\section{Az állami beavatkozások optimalizálása}

A belső energiapiac 2020-ra kitüzött céljai között szerepel a fenntartható, alacsony széndioxid-kibocsátású és energiahatékony rendszerek felé történő elmozdulás, egyrészt az alacsony kibocsátást biztosító beruházások (szén-dioxid leválasztás és tárolás) megvalósításával, másrészt a magas széntartalmú tüzelőanyagok alacsony széntartalmúakkal való helyettesítésével (Európai Parlament 2012). Mindez megköveteli a szükös állami források felhasználásának optimalizálását - annak érdekében, hogy az ilyen jellegü beruházásokat ösztönözni lehessen.

Jelenleg az állami forrásokat elsősorban a többnyire még gazdaságosan nem üzemeltethető megújuló energiát hasznosító technológiák támogatására használják fel. A megújuló energiaforrásokra vonatkozó nemzeti cselekvési tervekben foglalt vállalásoknak, a tagállami támogatási rendszereknek, valamint a $\mathrm{K}+\mathrm{F}$ tevékenységekbe való folyamatos befektetéseknek köszönhetően az Európai Unió megújulóenergia-ágazata sokkal gyorsabb ütemben fejlödött, mint amire a 2009-ben elfogadott 2009/28/EK irányelv kidolgozásakor számítani lehetett (Ecorys 2010). Ennek következtében a megújulóenergia-termelök egyre inkább az energiapiac meghatározó szereplőivé válnak. Ám a termelés - a jelentős állami források ellenére - eddig csak részterületeken, illetve földrajzi szempontból elönyös helyeken versenyképes a hagyományos módokkal szemben.

A tagállamok mintegy 170 különböző - közvetlen vagy közvetett - támogatási formát alkalmaznak. Ez a rendszer viszont jelentősen csökkenti a határokon átnyúló villamosenergia-kereskedelem hatékonyságát, mivel megtartja, sőt fokozza a meglévő egyenlőtlenségeket, akadályozza a piacra lépést, és gátolja a szereplőket az országhatár-független üzleti modellek kialakításában. Mindemellett a támogatási rendszerek drágák, növelik a végfogyasztói árakat, s nem ösztönöznek költséghatékonyabb termékek fejlesztésére.

A megújuló energiát előmozdító támogatási rendszerek bevezetésére a részleges piacnyitás és a fejlődés korai szakaszában járó technológiák fejlesztése miatt került sor. Időközben azonban mind a piacok, mind a technológiák jelentős változásokon mentek keresztül, ezért szükség van egy átfogó reformra. Olyan szisztémák fenntartása indokolt a jövőben, amelyek nem (vagy csak kis mértékben) torzítják a versenyt, valamint bizonyíthatóan nem áll rendelkezésre más, hatékonyabb, piaci alapú megoldás a beruházások megvalósítására.

20 Például Finnország, Hollandia, Egyesült Királyság, Svédország, Szlovénia, Ausztria, Csehország, Luxemburg, Németország. A Bizottság megállapodott a szabályozott árak fokozatos megszüntetéséröl Romániával, Görögországgal és Portugáliával.

${ }^{21}$ A Bíróság 2010. április 20-i ítélete szerint, a szabályozott ár csak szigorúan meghatározott körülmények esetén egyeztethetö össze az uniós joggal (általános gazdasági érdekű szolgáltatás nyújtása). 
A támogatási rendszereket tehát meg kell újítani ahhoz, hogy költséghatékonyan lehessen alkalmazni azokat, miközben törekedni kell a fokozatos megszüntetésükre. A befektetői bizalmat csökkentő hirtelen, vagy visszamenőleges hatályú változtatást azonban célszerü elkerülni. A magánberuházásoknak komoly szerepük van az új technológiák elterjesztésében, amelyek fejlesztése viszont ma még több területen nem valósítható meg támogatások nélkül. Pozitív példákat azonban már most is említhetünk. A 2010-ig tartó ötéves időszakban a fotovoltaikus rendszerek költsége közel 50 százalékkal, a szárazföldi szélerőművek beruházási költsége 2008 és 2012 között csaknem 10 százalékkal mérséklődött. Más technológiák fejlődési pályája ettől eltérő, továbbra is támogatásra lehet szükségük, de tőkeköltségeik a várakozások szerint szintén csökkenni fognak.

Mivel a klímapolitika és a megújuló energiaforrásokkal kapcsolatos politika egymást kölcsönösen kiegészítik, jól müködő szén-dioxid piacra és megfelelően kialakított energiaadókra van szükség ahhoz, hogy a beruházók egyértelmü ösztönzést kapjanak az alacsony szén-dioxid-kibocsátású technológiákba történő beruházásokhoz és fejlesztésekhez. A 2013ig eltelt időszakban az EU szén-dioxid-kereskedelmi rendszere többször az összeomlás szélére került, hitelessége megkérdőjeleződött ${ }^{22}$. Ez súlyos probléma, mert a nagyfokú bizonytalanság visszafogja a szén-dioxid-kibocsátás csökkentésére irányuló beruházásokat is.

A befektetői biztonság helyreállítása és a piaci alapú ösztönzők megerősítésére érdekében a rendszert alkalmassá kell tenni a piaci kihívások kezelésére ${ }^{23}$. Meg kell azonban jegyezni, hogy a szén-dioxid-kibocsátás növekedésének megakadályozására tett nemzetközi kísérletek eddig kudarcot vallottak (Helm 2012).

A megújuló forrásokból előállított energiát ugyanakkor - csökkenő mértékű támogatással, vagy támogatás nélkül - fokozatosan integrálni kell az energiapiacba, hogy idővel a hagyományos villamosenergia-termelőkhöz mérhetően, ugyanolyan versenyképes árakon tudjanak hozzájárulni az energiahálózat stabilitásához és az ellátásbiztonsághoz.

\section{Hálózatfejlesztések}

Az európai energiarendszerek komoly átalakulás előtt állnak, egy teljesen új típusú energiaellátási szisztéma van kialakulóban. Az európai hálózatfinanszírozási rendelet hangsúlyozza, hogyajövő energiahálózatait már a környezetvédelemközösségi vívmányaival összhangban kell megtervezni (COM 2011b). A transzeurópai energia infrastruktúrára vonatkozó iránymutatás (az úgynevezett energiainfrastruktúra csomag) pedig 12 kiemelt jelentőségű hálózatot és területet határoz meg a villamos energia, a gáz, az olaj és a széndioxid szállítására, tárolására (COM 2011a) $)^{24}$.

\footnotetext{
${ }^{22}$ Az ETS (Emissions Trading System) az EU energia-intenzív ipari szektorainak kibocsátás-kereskedelmi rendszere, amely az energiatermeléshez és -felhasználáshoz kötődő szén-dioxid-kibocsátásoknak közel felét érinti. Politikai döntéshozók határozzák meg, mennyi szén-dioxid-kibocsátást engedélyeznek, és a kibocsátás-kvótákat (például aukción, vagy ingyenes kiosztással) szétosztják a piaci szereplök között. Ezt követően utóbbiak egymás között adják-veszik a kvótákat, amíg az ahhoz nem kerül, aki azt a lehető legtöbbre értékeli (vagyis akinek a számára a legértékesebb a szén-dioxid-kibocsátás) - ezzel pedig egy hatékony rendszer, és piaci alapú szén-dioxid ár alakulhat ki.

${ }_{23}$ Erre irányuló kezdeményezés az Európai Unió 2013. júliusi 7-i döntése, amelynek értelmében átmenetileg csökkenteni fogják a szén-dioxid-kibocsátási engedélyek árverezését („,backloading”), mivel sokkal több kvóta van a piacon, mint amekkora a kereslet irántuk. A tonnánkénti kvótaárak 2005 és 2013 júliusa között 0 és 34 euró között ingadoztak.

${ }_{24}$ A rendelet célja többek között: 2020-ig a fizikai földgázforrások és útvonalak diverzifikált portfóliójának megvalósítása; új villamosenergia-tárolási technológiák fejlesztése; szén-dioxid mentes villamosenergia-rendszerre való átállás 2050-re; "Electricity Highways" kiépítése a többlet energia fogadására a termelési régiókból, és összekötése a föbb tárolási központokkal.
} 
Jelentős beruházásokra van szükség az elöregedő rendszerek cseréjéhez, a szén-dioxidmentes technológiák fejlesztéséhez, az energiahatékonyság és az ellátásbiztonság növeléséhez. A kulcsfontosságú infrastrukturális beruházások gazdaságilag nem minden esetben térülnek meg, ezért állami támogatást igényelnek. Az Európai Unió különféle eszközökkel (például Európai Hálózatfinanszírozási Eszköz ${ }^{25}$, kohéziós politika ${ }^{26}$, Horizont 2020 Program $^{27}$ ) próbálja a beruházásokat ösztönözni, amelyeket azonban fel kell gyorsítani, ha tartani kívánják a 2020-ra meghatározott célokat.

A piaci liberalizációt megelőzően a vertikálisan integrált nemzeti energiatársaságok a termeléstől a fogyasztásig ellenőrzésük alatt tartották a teljes energiarendszert. A versenyképes piac fejlődésével azonban ma már egyetlen társaság vagy cégcsoport sem képes garantálni az energiarendszerek megbízhatóságát, az ellátásbiztonságot és a fejlesztések összehangolt megvalósítását. A piac sokkal összetettebb, változékonyabb és sérülékenyebb lett, ami az energetikai társaságok számára növekvő kockázatokat hordoz, előtérbe helyezve ezzel a tagállamok közötti szorosabb együttmüködéseket.

A már most is tapasztalt piaci folyamatok, valamint az azokból következő változások alapvetően írják felül azt a korábban elfogadott hagyományos nézetet, amely szerint az energetikai közműszolgáltatások - alacsonyabb hozamok mellett ugyan, de - biztonságos befektetési területnek számítanak.

\section{A villamosenergia-rendszer stabilitásának fenntartása}

Miközben a villamosenergia-fogyasztás drasztikusan visszaesett, az uniós klímapolitika eredményeként jelentős mennyiségü megújuló kapacitás épült be az európai villamos energia rendszerbe. A kapacitások bővülése azonban nem járt együtt az ellátásbiztonság növekedésével.

A megújuló forrásokból származó energia többnyire decentralizált, terheléstől távol történő és időjárásfüggő betáplálásához a jelenlegi (hagyományos energiahordozókon alapuló) infrastruktúrától eltérő megoldásokról kell gondoskodni. A legkedvezőbb és legversenyképesebb helyszínek földrajzilag gyakran távol vannak a fogyasztás központjaitól, és ezek a helyszínek csak az átviteli hálózatok kiépítése után használhatók. Ez különösen olyan területeken fontos, ahol a betáplálás összehangolatlan, határokon átnyúló energiaáramlásokat („loop flow” ${ }^{28}$ okozhat, ami a terhelésbe történő fokozott beavatkozásokat tesz szükségessé az ellátás biztonságának fenntartása érdekében (Wagner 2012).

Az ellátás biztonsága érdekében - a megújuló energiatermelés ingadozó betáplálása miatt - szükség van a hagyományos termelésben eddig nem létező tartalékkapacitások kiépítésére is, amelyek viszont jelentős költséggel járnak. Több tagállam egyre inkább

25 Connecting Europe Facility (CEF): célja a közös érdeket képviselö stratégiai transzeurópai energetikai infrastruktúra projektek pénzügyi támogatása.

${ }^{26}$ A 2014 és 2020 közötti időszakra vonatkozóan a Bizottság javasolja, hogy az EU a kohéziós alap forrásait koncentrálja a megújuló energiaforrásokra és az energiahatékonyságra, beleértve az intelligens hálózatokat, valamint kezelje kiemelten a kutatás-fejlesztést és az innovációt.

${ }_{27}$ A Horizont 2020 Program a K+F tevékenység támogatását célozza.

28 Párhuzamos áramlás (loop flow) akkor fordul elö, ha a villamos energia tényleges fizikai áramlása az infrastruktúra hiánya miatt nem a szerződéses útvonalat követi. Klasszikus példája az Észak-Németországból Dél-Németországba Lengyelországon és a Benelux-államokon keresztül továbbított villamos energia; erre Németország észak-déli átviteli infrastruktúrájának elégtelensége miatt van szükség. 
szorgalmazza egy olyan támogatási forma bevezetését, amely gazdaságilag vonzóbbá tenné a hagyományos tartalékok kiépítését és fenntartását. A termelő kapacitások piaci rendelkezésre állására elkülönített támogatási rendszerben (Capacity Mechanism, vagy Capacity Remuneration Mechanism - CRM) ${ }^{29}$ a tagországok kormányai határoznák meg a termelési kapacitás kívánt szintjét. Ez olyan hosszú távú szabályozási eszköz lenne, amely bevételt jelenthetne a termelők számára, és a rendelkezésre álló kapacitás megfizetésére kötelezné a fogyasztókat. Szükségességét azzal indokolják, hogy a megtermelt energiára összpontosító piacok nem ösztönzik kellőképpen azokat a termelő beruházásokat, amelyek hosszú távon garantálhatják az ellátásbiztonságot (IEA 2011).

A Bizottság véleményében óvatosan fogalmaz, s inkább a negatívumokat emeli ki. A megfelelö uniós szintű koordináció hiánya vagy a túl korai bevezetés éppen ellentétes hatást válthat ki. Fennállhat a veszélye, hogy háttérbe szorulnak a rugalmas keresletoldali reagálást lehetővé tevő termelő invesztíciók, mivel az új eszköz függetlenítheti a beruházási döntéseket a piaci árjelzésektől. Előtérbe kerülhetnek a fosszilis tüzelőanyagok, ezzel hátráltatva a szén-dioxid-mentesítésre vonatkozó uniós célkitüzések teljesülését (COM 2012). A rendszer továbbá hozzájárulhat a nemzeti piacok szegmentálásához és a határkeresztező kereskedelem mérséklődéséhez is, ezért a Bizottság javasolja, hogy azt vonják be az állami támogatásokra vonatkozó szabályok hatálya.

Annak érdekében, hogy ez a fajta piaci szabályozás a kívánt rugalmasságot biztosító beruházásokat indukáljon, a kiegyenlítő energia piacok kiterjesztésével jóval több szereplőt, új terméket és technológiát szükséges a folyamatokba bevonni. A rendszer bevezetésének piaci alapúnak, technológia-semlegesnek és diszkriminációmentesnek kell lennie, figyelembe véve a megfelelő szintủ régiós rendszer-összeköttetések biztosítását is.

A vélemények tehát megoszlanak a kapacitás díj rendszerről, $s$ a vita még koránt sincs lezárva. A Bizottság javaslata szerint a tagállamoknak az okok részletes magyarázatával teljes körűen elemezniük kell az energetikai beruházások területén tapasztalható változásokat, mielőtt nemzeti hatáskörben a kapacitás díj szisztémára vonatkozóan bármilyen intézkedést terveznének.

\section{Intelligens hálózatok}

$\mathrm{Az}$ energiarendszerek infrastrukturális átalakításának egyik módja (az átviteli- és elosztóhálózatok fejlesztése mellett) az intelligens hálózatok kiépítése, a keresleti és a kínálati oldali szabályozás rugalmasságának javítása érdekében. Erre jelenleg különösen a villamosenergia-rendszerek esetében van szükség. A szél- és a napenergia egyre nagyobb részesedésével a villamosenergia-termelésben - a keresleti oldal mellett - a kínálati oldalon is volatilitással kell számolni, mivel a termeléshez felhasznált erőforrás rendelkezésre állása bizonytalan. A kereslet és a kínálat közötti mindenkori egyensúly megőrzése ezért számos kihívás elé állítja a villamosenergia-rendszert müködtetőket. A stabilitás fenntartásához mindkét oldal rugalmasságát növelni szükséges, ami piac-összekapcsolások, intelligens hálózatok és új energiatárolási technológiák alkalmazásával valósítható meg.

Ennek az új integrált infrastruktúrának az alapját a digitális infrastruktúra képezheti, amely a jövő energiaellátásában egyre fontosabb szerepet fog játszani. Azinfokommunikációs és az energiapiaci szereplők közötti infrastrukturális és szolgáltatási szinergiák (például

${ }^{29}$ Capacity Remuneration Mechanism (CRM): kapacitás díjazási rendszer. 
komplementer szolgáltatások) kihasználásával pedig lehetőség nyílhat új innovatív szolgáltatások és szolgáltatók megjelenésére az energiapiacon.

Azintelligens fogyasztásmérő szisztémák elterjedésével és a háztartások automatizálásával a fogyasztók energiaigényeiket egyre inkább az energiapiac aktuális helyzetéhez tudják majd igazítani: kihasználhatják a völgyidőszakok alacsony árait, illetve a csúcsperiódusban mérsékelhetik a fogyasztásukat. Az elektronikusan továbbított árjelzésekre reagálva lehetővé válhat számukra, hogy az alacsonyabb árakat kihasználva alakítsák ki fogyasztási szokásaikat (Wallenborn 2011). A dinamikus árjelzések a kínálati oldal rugalmasságát is növelhetik, hiszen a termelési vagy az energiatárolási kapacitást gyorsan hozzá lehet igazítani a változó kereslethez. Ezek a szolgáltatások dinamikus online hálózatkezeléssel kiegészítve akár helyi vagy otthoni energiakereskedésre is alkalmasak lehetnek. Ezen túlmenően, az egyedi „keresletoldali visszajelzéseket” összesítve jelentős fogyasztási megtakarítás érhető el magas energiaárak idején, ezzel viszont javítható az energiarendszerek hatékonysága és stabilitása. A fogyasztási görbe ilyen jellegü „kisimítása” csökkenti a csúcsidőszaki termelési igényt, ami viszont komoly anyagi megtakarítást eredményezhet az energiapiac szereplői számára.

Az új innovatív szolgáltatások sikere nem kizárólag attól függ, hogy a társaságok mennyire tudják követni a fogyasztói elvárásokhoz kapcsolódó keresletoldali változásokat, hanem szükség van rugalmas árképzési rendszerek kialakítására is (Klopfert-Wallenborn 2011). A termelöknek, a fogyasztóknak és a hálózatüzemeltetőknek valós idejü kommunikációt kell folytatniuk annak érdekében, hogy a keresletet és a kínálatot optimálisan meg tudják feleltetni egymásnak.

Ez irányú elmozdulást jelent a tagállamok villamosenergia-piacainak összekapcsolási folyamata (market coupling). A versenypiaci feltételek mellett müködö rövid és hosszú távú nagykereskedelmi villamosenergia-piacok (másnapi, napon belüli és kiegyenlítő piacok, kiegészítő szolgáltatások piacai) mindenkor és minden régióra vonatkozóan jelzik a villamos energia éppen aktuális gazdasági értékét. A piac-összekapcsolás a kockázatok mérsékléséhez is hozzájárul, mivel a kereslet hirtelen növekedése, illetve csökkenése nem egyszerre jelentkezik majd minden tagországban.

Ezen a területen elsődleges megoldandó feladat az energiatermelés és -felhasználás új formáinak sajátságait tükröző, a határokon átnyúló energiapiacok fejlődését elösegítő piaci és szabályozási modellek, egységes hálózati szabályok kidolgozása és életbe léptetése (Commission decision 2012). Az intelligens fogyasztásmérés, illetve a mikro és megosztott energiatermelés együttes alkalmazása szintén komoly elörelépést hozhat a jövőben az energiahálózatok fejlesztésénél. Az úgynevezett micro generation és a megosztott (distributed generation) energiatermelés megjelenése részben vagy akár teljes egészében is függetlenítheti a fogyasztókat a hálózati energiaellátástól ${ }^{30}$. Ők maguk is energiatermelőkké, „fogyasztótermelőkké” válnak, ezért igyekeznek jobban kézben tartani saját fogyasztásukat. Ez a fajta energiatermelés ma még elsősorban a villamosenergia-ellátásban játszik szerepet, de a technológiák fejlődésével a lehetőség adott a földgázellátás esetében is ${ }^{31}$.

30 Micro generation: háztartási méretű kiserőmü; distributed generation: kisméretű erőmű. Például fotovoltaikus, vagy szélenergiára, biomasszára, geotermikus energiára épülő, kapcsolt hő- és villamosenergia-termelő rendszer, gázerőmü, amely hozzájárulhat lakó- és irodaépületek, ipari létesítmények energiaellátáshoz.

${ }^{31}$ A helyben zajló és részben helyben felhasznált decentralizált energiatermelés révén rendszerszinten csökkenthető a hálózati és átalakítási veszteség, mérsékelve ezzel az energiaellátás költségeit és javítva az energiahatékonyságot. 
A mikro és a megosztott (megújuló forrásokra épülő) energiatermelés elterjedése miatt, valamint a keresletoldali visszajelzések gyors követése érdekében, szükség van az elosztó hálózatok fejlesztésére. Ezek a hálózatok juttatják el a villamos energiát a végfogyasztókhoz, a kistermelőktől érkező, betáplált energiát azonban jelenleg nem képesek befogadni.

Az új típusú kínálati oldali betáplálás szükségessé teszi az elosztó hálózatot üzemeltetők hatáskörének újragondolását is. A szabályozott tevékenységeket a természetes monopóliumként értelmezett feladatokra célszerü korlátozni. Törekedni kell arra, hogy az új technológiák révén elérhető új szolgáltatások kidolgozása versenyképes piacon történjen, és mérlegelendő a harmadik felek (például informatika, távközlés) képviselőnek a bevonása is az elosztó hálózati fejlesztésekbe.

Miközben a megújuló forrásokból származó energia hálózatba történő betáplálása az átviteli infrastruktúrák fejlesztését igényli, a megosztott termelés növekedésével (elosztó hálózati fejlesztésekkel) csökkenthető az átviteli infrastruktúra iránti igényt.

\section{Összefoglalás}

A 2011-ben hatályba léptetett 3. energetikai jogszabálycsomag végrehajtása jelenleg is tart. Célja, hogy a tagállami villamosenergia- és földgázpiacok integrálásával 2014re létrejöjjön egy egységes uniós energiapiac. A fogyasztók számára ez valódi választási lehetőséget teremtene a szolgáltató- és szolgáltatás-választásban, s minden uniós tagállam számára biztosítaná az európai energiahálózatokhoz való szabad hozzáférést, megszüntetve ezzel több tagállam elszigeteltségét. Az energiapiaci integráció és az ehhez szükséges infrastruktúrafejlesztések pedig hozzájárulhatnak a régiók közötti árkülönbségek kiegyenlítődéséhez, ami már középtávon is jelentős változásokat indukálhat.

$\mathrm{Az}$ úgynevezett energiainfrastruktúra-csomag, amely kiegészíti a belső energiapiacról szóló irányelveket, az infrastruktúra tervezésének, fejlesztésének és üzemeltetésének jobb összehangolását segítö, valamint az intelligens hálózatok általános bevezetését szolgáló intézkedéseken keresztül biztosíthatja az integrált európai energiainfrastruktúra kiépítését. Az energiaágazat átalakításához mindkét kezdeményezés végrehajtása elengedhetetlen. Az egységes piac létrejötte, az új technológiák, piaci szereplők és komplementer szolgáltatók megjelenése szintén az új infrastruktúra kiépülésének függvénye.

Az európai energiahálózatokat úgy kell korszerüsíteni, hogy biztosítsák a megújuló energiatermelés, a micro és megosztott termelés rendszerbe integrálását, $s$ támogassák az intelligens hálózatok kiépítését, amelyek átalakítják, optimalizálják az energiafogyasztás és a termelés szerkezetét, valamint csökkentik annak mértékét. Emellett szükség van a különböző piaci szereplők (hálózatüzemeltetők, termelők, szolgáltatók, fogyasztók, szabályozó hatóságok) feladatait pontosan meghatározó szabályozási keretek kiépítésére. Azt az egyre erősödő tendenciát pedig, hogy a tagállami kormányok egymással nem egyeztetve hoznak szabályozási döntéseket, meg kell állítani.

A 2020-ra kitűzött energiastratégiai célok elérése, illetve az energiarendszerek 2050-ig történő átalakítása érdekében több területen fel kell gyorsítani a változásokat. Az európai energiarendszerek biztonsága és fenntarthatósága is veszélybe kerülhet, ha nem sikerül a versenypiaci feltételek megteremtésének útjában álló akadályokat leküzdeni. Ezen felül 2020-ig komoly befektetésekre lesz szükség az uniós energiahálózatok korszerüsítése, az energiahatékony és alacsony szén-dioxid-kibocsátású rendszerek kiépítése érdekében. 
A globális éghajlatvédelemhez való hozzájárulásként az EU vállalta, hogy az 1990-es szinthez képest 2050-ig 85-90 százalékkal mérsékli az üvegházhatású gázok kibocsátását. Mindezt úgy kell megvalósítania, hogy a közösség ne gyengítse saját gazdasági erejét, az európai ipar ne kerüljön további versenyhátrányba a nemzetközi szintéren.

$\mathrm{Az}$ energiatermeléssel összefüggő szén-dioxid-kibocsátás visszafogása és az importfüggőség csökkentése érdekében a megújuló források felhasználásának támogatása prioritást élvez az Európai Unióban. A támogatási formákat azonban felül kell vizsgálni. Olyan támogatási eszközök szükségesek, amelyek környezeti, társadalmi és gazdasági célok elérését szolgálják, de ugyanakkor tükrözik a felmerülö költségeket is. Amennyiben sikerül közös támogatási rendszereket létrehozni, a beruházások költséghatékonyabban valósíthatók meg, $s$ a szemléletmód egyre inkább igazodik majd az egységes piaci elvekhez.

\section{Hivatkozások}

Bírósági ítélet (2010): Az Európai Bíróság itélete a C 265/08 számú ügyben. Az Európai Unió Hivatalos Lapja, 2010. 06. 19.

COM (2010): A Bizottság közleménye az Európai Parlamentnek és a Tanácsnak a regionális kezdeményezések jövőbeni szerepéről. COM(2010) 721, végleges verzió. 2010. 12. 07., Brüsszel.

COM (2011a): Az Európai Parlament és a Tanács rendelete a transzeurópai energiainfrastruktúrára vonatkozó iránymutatásokról. $\operatorname{COM(2011)~658,~végleges~verzió,~2011.~10.~19.,~Brüsszel.~}$

COM (2011b): Az Európai Parlament és a Tanács rendelete az európai összekapcsolódási eszköz létrehozásáról. $\operatorname{COM}(2011)$ 665, végleges verzió, 2011. 10. 19., Brüsszel.

COM (2011c): Macro-Economic Report. COM(2011) 815, final, 2011. 11. 23., Brüsszel.

COM (2012): A Bizottság jelentése az Európai Parlamentnek és a Tanácsnak: az európai szén-dioxid-piac helyzete 2012-ben. $\operatorname{COM(2012)~652,~végleges~verzió.~2012.~11.~14.,~Brüsszel.~}$

Commission decision (2002): A Bizottság határozata az üzemi és kereskedelmi szabályzatok és az iránymutatások kidolgozásához szükséges éves prioritási listák 2013-ra történö létrehozásáról. 2012. 07. 19., Brüsszel.

ECME Consortium (2010): The functioning of retail electricity markets for consumers in the European Union. DG Health and Consumers / ECME Consortium, Brüsszel.

Ecorys (2010): Assessment of non-cost barriers to renewable energy growth in EU Member States. DG Energy and Transport / Ecorys, Rotterdam.

Energy Market Observatory (2012): Price developments on the EU retail markets for electricity and gas 1998-2011. http://ec.europa.eu/energy/observatory/electricity/doc/analysis_retail.pdf.

Európai Parlament (2012): Állásfoglalás: a 2011-2020-as időszakra vonatkozó új európai energiastratégia felé. 2010. 11. 25., Strasbourg.

European Commission (2012): Energy Market in the European Union in 2011. Publications Office of the European Union, Luxembourg.

Helm, D. (2012): The Carbon Crunch - How We're Getting Climate Change Wrong and How to Fix It. Yale University Press, New Haven, CT.

IEA (2011): Harnessing variable renewables: A Guide to the Balancing Challenge. International Energy Agency, Párizs.

Irányelv (2009): Az Európai Parlament és a Tanács 2009/28/EK irányelve a megújuló energiaforrásból elóllított energia támogatásáról. Az Európai Unió Hivatalos Lapja, 2009. 06. 05.

Klopfert, F. - Wallenborn, G. (2011): Empowering Consumers through Smart Metering - Report for the BEUC, The European Consumer Organisation. BEUC, Brüsszel.

REMIT (2011): Az Európai Parlament és a Tanács 1227/2011/EU rendelete a nagykereskedelmi energiapiacok integritásáról és átláthatóságáról. Az Európai Unió Hivatalos Lapja, 2011. 12. 08.

Stromback, J. - Dromacque, D. - Yassin, M. H. (2011): The potential of smart meter enabled programs to increase energy and systems efficiency: a mass pilot comparison. VaasaETT Global Energy Think Tank, Helsinki. 
Wagner, F. (2012): Features of an electricity supply system based on variable input. EPJ Web of Conferences, Vol. 54.

Wallenborn, G. - Orsini, M. - Vanhaverbeke, J (2011): Household appropriation of electricity monitors. Journal of Consumer Studies, Vol. 35, No. 2:146-152. 